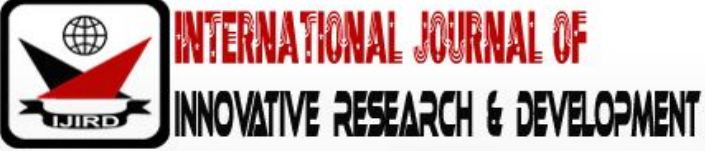

ISSN 2278 - 0211 (Online)

\section{Assessment of Staff Contentment and Inspiration for the Organizational Success: The Case Study of Some Selected State Bank of India, in Andhra Pradesh, Visakhapatnam}

\section{Addisu Tesema Tanga}

Lecturer, Department of Management, Jigjiga University, Ethiopia

\section{Abstract:}

The main objective of the study was to asses Staff Contentment and inspiration for the organizational Success in the Case study of some selected State bank of India. In the meantime, it aimed at assessing major factors that affect employees' Contentment and Inspiration and their impact on organizational Success. To achieve these objectives, the study employed descriptive survey method. In this study both primary and secondary data were used. The primary data obtained from questionnaires distributed for employees of the company's and secondary data were obtained from the different books, annual plan, and documents of the organization. Out of the total of 109 (100\%) employees, 75(68.80\%) sample population were selected using Simple random sampling method. However, considering four (4) unreturned questionnaire, only 71(65.13\%) employees participated in the study. Collected data were analyzed both quantitatively using percentile and qualitatively through document narration. This study revealed that almost all employees were not satisfied due to finance, lack of training and incentives. Majority of the employees believed that inspiration has high impact on the organization performances. The bank's Incentive package was unattractive and could not achieve high quality work. The organization did not follow open door policy. This study also indicated low relationship among employee's satisfaction, motivation and organization performances. Therefore, the organization should reform the incentive package and the work system should be inclusive of the employees.

Keywords: Staff contentment, staff inspiration, organizational success

\section{Introduction}

\subsection{Background of the Study and Its rationalization}

Contentment \&Inspiration area set of attitudes which predisposes a person to act in a specific goal directed way. Contentment is an inner state that energizes, channels and sustains human behavior to achieve goals and also work inspiration is concerned with the attitudes that channel a person's behavior toward work and away from recreationor other life activity areas. Inspiration is one of the key elements in employee performance \& productivity. Managers who can create the good work environment in the organization would most optimally sustain employee's inspiration. Managers in different organization need something to keep employees and most of the time managers assume that paying onlythe salary of the employee is enough to retain employees who work for the organization. However, sometimes just working for salary is not enough for employees to retain them in the organization. If no inspiration is present inan employee, then that employee's quality of work or all work in general would be deteriorate.

\subsection{Statement of the Problem}

Contentment and inspiration are vital for development of every organization. Both are an engine for the improvement of organization performances. In most state bank of Indian (SBI) inspiration is not properly used like other companies. The Study addresses the following research questions

- What are the factors that affect the employees Contentment \& Inspiration in SBI?

- What is the attitude of employees and managers to ward Contentment \& Inspiration?

- How Contentment \& Inspiration activities are under taken in the organization?

- Is there direct or positive relationship between Contentment, Inspiration and organizational performance or not?

- What is the impact of employees Contentment \& Inspiration in the organization performances? 


\subsection{Objective of the Study}

\subsubsection{General Objective}

The general objective of the study is to assessor analyze role of employees Contentment\& Inspiration on organization performance in state bank of India, Visakhapatnam and to give the appropriate recommendation on how to improve the existing situation.

\subsubsection{Specific Objective}

To asses by whom and for whom SBI's Inspiration activities is given

- To identify weather there is experience of using Inspiration to increase employee's performance or not.

- To identify alternative solution and give recommendations based on finding.

- To Examine how SBI implement Inspiration

- To Know the impact of Contentment\& Inspiration activities for SBI

\section{Research Design and Methodologies}

\subsection{Study Population \& Sample Size}

The Population of the study are the three branch employees of the State bank of India in Visakhapatnam. The total populations are 109 and all are permanent. The sample size was 75 (68.80\%) out of total permanent employees and from each branch 25 (33.33\%) respondents have been selected

\subsection{Sampling Techniques}

The study used simple random sampling techniques for all permanent staffs and random sampling methods have been used in all three branches.

\subsection{Source of Data}

In the study primary and secondary data source was used. The researcher was collected data from employees of the state bank of India at different levels of work are as in three branch and from different written documents of the organization.

\subsection{Method of Data Gathering}

To achieve the objectives, the study employed descriptive survey method. In this study both primary and secondary data were used. The primary data is collected through questioners from employees and the management body of the organization. The secondary data was collected from different books, published and unpublished documents and papers.

\subsection{Method of Data Analysis}

Collected data were analyzed both quantitatively using percentile and qualitatively through document narration.

\section{Data Analysis and Discussion}

This part deals with the presentation, analysis and interpretation of data collected through questionnaires. The study tries to assess if there are problems which are considered as obstacle for the employees' contentment and inspiration in the State bank of India Visakhapatnam. From the total number of 109 employees, the questionnaires were distributed for 75 employees of the organization from these 71 have completed and returned the questionnaires. Therefore, the analysis is made based on only 71 returned questionnaires.

\subsection{Demography of Respondents}

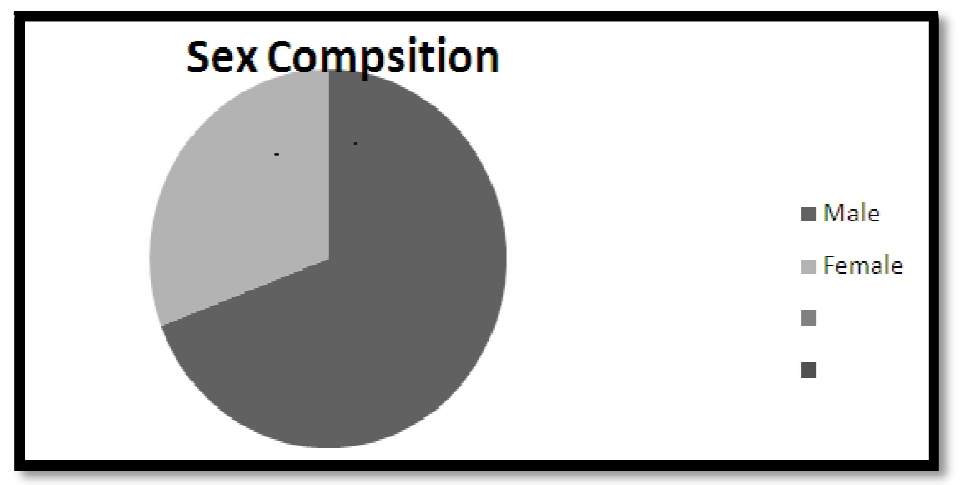

Figure 1: Sex of Respondents

As shown in Figure 1, the organization's sex composition indicates that $45(63.38 \%)$ are male and 26 (36.61\%) are female this shows that male have greater or higher participation than female in the organization. 


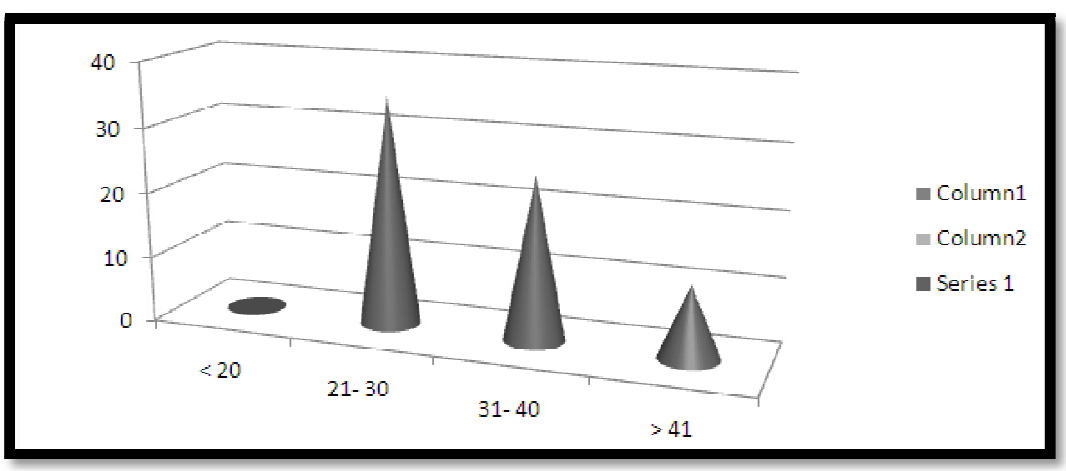

Figure 2: Age of respondents

As shown in figure 2, age of the sample population indicates that35(49.29\%) are between21 - 30, 25(35.21\%) are between $31-40$ and 11(15.49\%) are the age of greater than 41 years. This data reveals that from the total respondent more number of employees has the age of between 21 - 30 and the next employee working in State bank of India are also have age of between 31 - 40.and there is no employees blow 20 years. From this conclude the majority of employees with the organization are middle age or Adolescent.

\subsection{Educational Level}

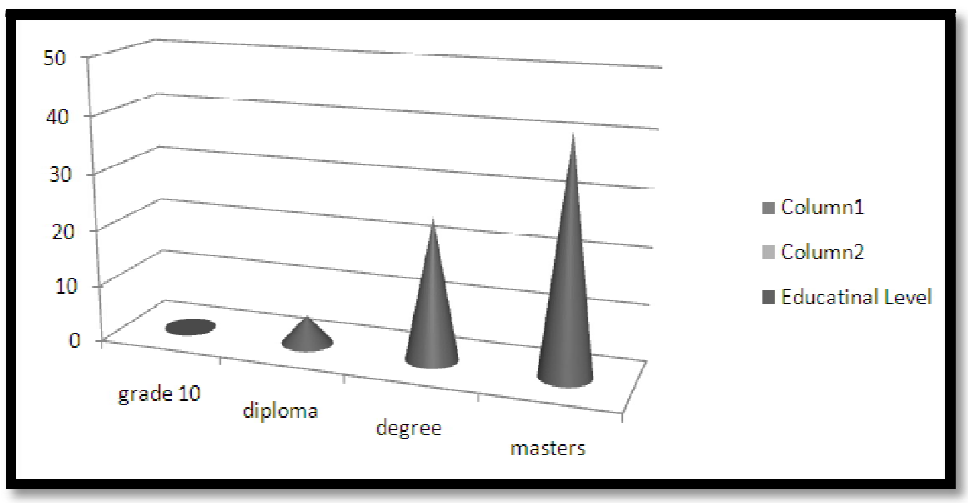

Figure 3

As shown in figure 3, the educational level of employees in state bank of India shows that 25(35.21\%) of employees are college / university first degree holders, 5(7.04\%) employees are diploma holders, while 41(57.74\%) or the majorities of the employees are master's degree holders and no below grade 10. From the above result we can understand that the organization has majority of masters' degree holders and good number of qualified employees which indicates that the state bank of India has currently run by employees who have sufficient required capacity.

\subsection{Types of Employees}

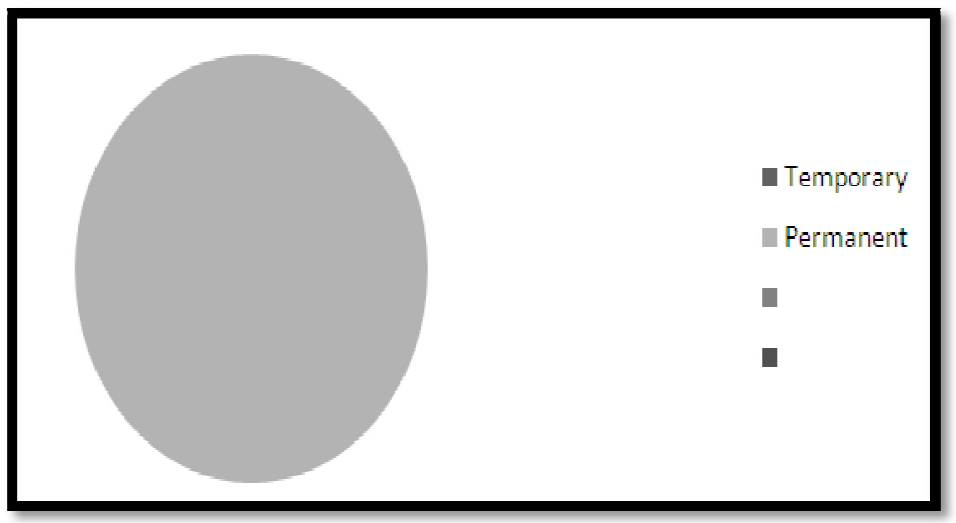

Figure 4

As shown in Figure 4, the types of employment with in the state bank of India, all employees are permanent this is $71(100 \%)$ are permanent and $0(0 \%)$ are temporary employees. from this chart almost, all employees are permanent. This shows there is job Security. 
3.4. Work Experience of Employees in a Year

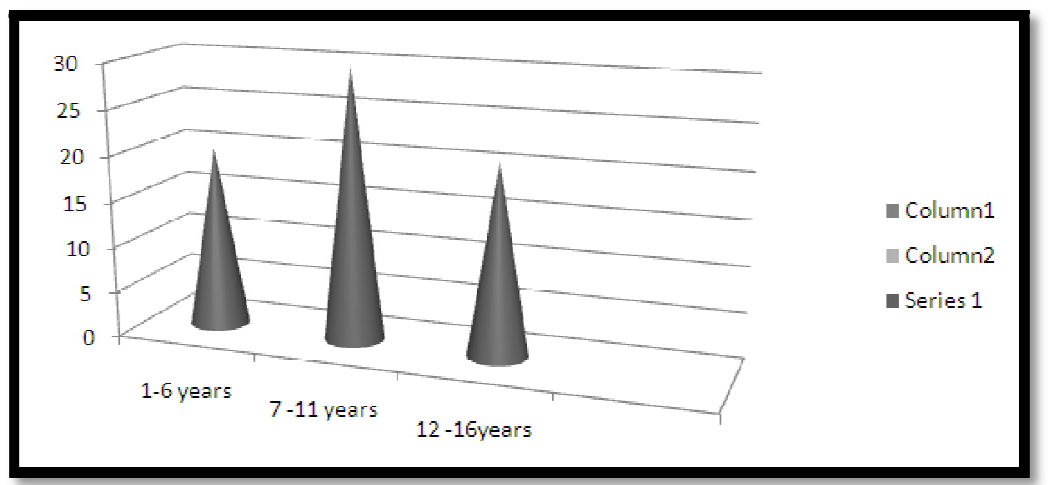

Figure 5

As shown in figure 5, the collected data shows that 20(28.16\%) employees have work experience of 1 - 6 years, 30(42.25\%) have 7 - 11 and 21(29.57\%) employees have12 - 16 years' experience from this we can conclude that the majority of employees have high work experiences within the organization. This implies the low turnover which mean the organization has high capacity to retain its employees so we can conclude that the employees are inspired or motivated

\subsection{Employee's Inspiration/ Motivation Techniques}

\begin{tabular}{|c|c|c|c|}
\hline No & Item & \multicolumn{2}{|c|}{ Respondent } \\
\cline { 2 - 3 } & & Number & Percentage \\
\hline & Which employee's motivation & & \\
& technique you prefer: - & 45 & $63.38 \%$ \\
& Financial motivation & 18 & $25.35 \%$ \\
& Non-Financial motivation & 8 & $11.26 \%$ \\
\hline & Both of them & 71 & 100 \\
\hline
\end{tabular}

Table 1: Motivation Techniques

The above table 1, shows that out of 71 respondents $45(63.38 \%)$ of them prefer financial reward system or they are motivated by financially. On the other hand, 18(25.35\%) of them said non-financial motivation system is preferable. And $8(11.26 \%)$ employees of them also said both. Therefore, to conclude from table 1 that the majority of employees prefer financial reward system or inspired if they get financial reward.

\subsection{The Satisfaction of Employee Motivation}

\begin{tabular}{|c|c|c|c|}
\hline No & Item & \multicolumn{2}{|c|}{ Respondent } \\
\cline { 3 - 4 } & & Number & Percentage \\
\hline \multirow{4}{*}{ Are you satisfied with motivational } & & \\
& technique of the organization & 20 & $28.17 \%$ \\
& Yes & 51 & $71.83 \%$ \\
\hline No & 71 & 100 \\
\hline & Total & & \\
& If you answer for the above question is No, & 37 & $72.55 \%$ \\
& what is the reason. & 8 & $3.69 \%$ \\
& Less payment of salary & - & - \\
& Lack of incentive or bonus & & \\
& Lack of training & 4 & 100 \\
\hline
\end{tabular}

Table 2: Employee's Satisfaction by Motivational Technique

As shown in Item 1 Table2, out of total respondents 51(71.83\%) of respondent replied that they are not satisfied by motivational technique used by the Bank. And the rest of employees 20(28.17\%) said they are satisfied with motivation technique. This result shows the majority of respondent employees are not satisfied which the motivational techniques. So, the organizations need to increase and improve the motivational technique of the organization in order to increase the number of satisfied employees. 
As indicate in Item 2 table 2, the respondents replied that the reason for dissatisfaction are 37(72.55\%) due to less salary payment, $2(3.92 \%)$ due to lack of training, $8(15.69 \%)$ are due to lack of incentive bonus and $4(7.84 \%)$ have given other reason for dissatisfaction. This table shows that the majority of respondent said less payment of salary. So, the organization might need to revise the salary scale and improve the other factors to eliminate the degree of employees' dissatisfaction.

\subsection{The Contribution of the Motivational Techniques in the Performances of the Organization}

\begin{tabular}{|c|c|c|c|}
\hline \multirow{2}{*}{ No } & Item & \multicolumn{2}{|c|}{ Respondent } \\
\cline { 3 - 4 } & & Number & Percentage \\
\hline \multirow{4}{*}{} & How you rate the contribution of the & & \\
motivational techniques in the & & \\
& performances of the organization & & $30.98 \%$ \\
& High & 22 & $56.34 \%$ \\
& Average & 9 & $12.68 \%$ \\
\hline Low & 26 & 100 \\
\hline
\end{tabular}

Table 3: Employee's Motivational Techniques

As shown in Item 1 Table 3, the contribution of the employee's motivational techniques in the performances of the organization shows $40(56.34 \%)$ average, 22(30.98\%) of the respondent are high performance and 9(12.68\%) said low performances. For this result the majority of respondent employees say that the relationship between motivation and the organization performances are average this indicates that motivation and performances have in different relationship on the organization.

\subsection{The Level of Motivation}

\begin{tabular}{|c|c|c|c|}
\hline No & Item & \multicolumn{2}{|c|}{ Respondent } \\
\cline { 3 - 4 } & & Number & Percentage \\
\hline \multirow{4}{*}{ How do you rate the level of motivation given in } & & \\
& your organization & & \\
& Very high & 16 & $22.54 \%$ \\
& High & 21 & $29.58 \%$ \\
& Low & 32 & $45.07 \%$ \\
& Very low & 2 & $2.82 \%$ \\
\hline & Total & 71 & 100 \\
\hline
\end{tabular}

Table 4: The Level of Inspiration/ Motivation in the Organization

As shown in item1 table4, the level of motivation rate $32(45.07 \%)$ of the majority respondent said low, $16(22.54 \%)$ said high rate and $21(29.58 \%)$ said very high, and $2(2.82 \%)$ said very low. These indicate that the majority respondent said that low rate of motivation given in the organization. So, I asked for their reason and their response is summarized as follow.

- There is motivation in the organization but it is not effective.

- Even if all types of motivations exist at all level but no one reliable and transparent.

- The salary scale is low and it does not have as such good compensation package.

3.9. The Impact of Motivation on the Organization Performance

\begin{tabular}{|c|c|c|c|}
\hline No & Item & \multicolumn{2}{|c|}{ Respondent } \\
\cline { 3 - 4 } & & Number & Percentage \\
\hline \multirow{2}{*}{$\begin{array}{c}\text { Do you think that motivation of employees } \\
\text { has impact on the organization } \\
\text { performance? }\end{array}$} & & \\
& Yes & 68 & $95.77 \%$ \\
& No & 1 & $1.41 \%$ \\
& Do not know & 2 & $2.82 \%$ \\
\hline & Total & 71 & 100 \\
\hline
\end{tabular}

Table 5: Impact of Inspiration/ Motivation

As shown in Item1, table 5, 68(95.77\%) respondent say yes,1(1.41\%) respondent say No, and 2(2.82\%) of respondent say do not know. This indicated that the majority of respondents said that there is impact of motivation on the organization performances and I ask the respondent why? And their response is summarized as flow.

- Because of it increases the efficiency, profitability and belongingness of the organization. 
- Because of the back bone of the organization are employees. So that it is must to motive employees.

- Because of unmotivated worker takes his work negligently no due care in his performance, strongly affects the organization.

- Because of motivation is recognition for once job contribution and effort.

- Because of motivation is an incentive to build the moral of the employees' performances.

- Because if there are motivated employees, they can perform their job properly and they can make the organization profitable.

\subsection{Employee's Contribution of the Organization}

\begin{tabular}{|c|c|c|c|}
\hline No & Item & \multicolumn{2}{|c|}{ Respondent } \\
\cline { 3 - 4 } & & Number & Percentage \\
\hline \multirow{4}{*}{} & Do you think that the organization properly & & \\
& recognizes your contribution to the & & \\
& organization & 42 & $59.15 \%$ \\
& yes & 23 & $32.39 \%$ \\
& No & 6 & $8.45 \%$ \\
\hline & Do not know & 71 & 100 \\
\hline
\end{tabular}

Table 6: Recognition of Employees' Contribution of the Organization

As shown in Item 1 table 6, 42(59.15\%) of the respondent employees said the organization properly recognizes their contribution to the organization, $23(32.39 \%)$ of the respondent employees said that the organization do not recognizes their contribution to the organization, 6(8.45\%) said do not know. Therefore, the majority said that the organization properly recognizes their contribution to the organization. This is good for employees for increasing the sense of belongingness (ownership)

\subsection{Employees Participation on Decision Making Process}

\begin{tabular}{|c|c|c|c|}
\hline \multirow[t]{2}{*}{ No } & \multirow[t]{2}{*}{ Item } & \multicolumn{2}{|c|}{ Respondent } \\
\hline & & Number & Percentage \\
\hline & $\begin{array}{c}\text { Do you think that an employee should participate in the } \\
\text { decision-making process } \\
\text { Yes } \\
\text { No } \\
\text { Do not know }\end{array}$ & $\begin{array}{c}64 \\
6 \\
1\end{array}$ & $\begin{array}{c}90.14 \% \\
8.45 \% \\
1.41 \%\end{array}$ \\
\hline & Total & 71 & 100 \\
\hline & $\begin{array}{c}\text { If your answer is "yes" have you participated in the } \\
\text { decision-making process? } \\
\text { Yes } \\
\text { No }\end{array}$ & $\begin{array}{l}25 \\
39\end{array}$ & $\begin{array}{l}39.06 \% \\
60.94 \%\end{array}$ \\
\hline & Total & 64 & 100 \\
\hline
\end{tabular}

Table 7: Employees Participate in Decision Making

For the question asked in table 7 item 1, the majority of respondent $64(90.14 \%)$ said yes, $6(8.45 \%)$ said no and $1(1.41 \%)$ said do not know. This indicates that the large number of employees or the majority of employees are accepted to participate in decision making process. As it can be seen in item 2, table 7 the majority of employees 39(60.94\%) have no participation in decision making process and only 25(39.06\%) have a participation in decision making. These indicate that the majority of employees are not participated in decision making process.They may cause de-motivation. This effect is decreasing employees' interest to work, inattentiveness and low-level sense of importance and also may create problem in implementing the decision made. 


\subsection{Open Door Policy}

\begin{tabular}{|c|c|c|c|}
\hline \multirow[t]{2}{*}{ No } & \multirow[t]{2}{*}{ Item } & \multicolumn{2}{|c|}{ Respondent } \\
\hline & & Number & Percentage \\
\hline & $\begin{array}{c}\text { Do your organization follow open door policy } \\
\text { Yes } \\
\text { No } \\
\text { Do not know }\end{array}$ & $\begin{array}{c}12 \\
56 \\
3\end{array}$ & $\begin{array}{c}16.90 \% \\
78.87 \% \\
4.23 \%\end{array}$ \\
\hline & Total & 71 & 100 \\
\hline & $\begin{array}{c}\text { If your answer is yes, do you think that having this } \\
\text { policy increase your performance } \\
\text { Yes } \\
\text { No } \\
\text { Do not know }\end{array}$ & $\begin{array}{c}11 \\
- \\
1\end{array}$ & $\begin{array}{c}91.67 \% \\
8.33 \%\end{array}$ \\
\hline & Total & 12 & 100 \\
\hline
\end{tabular}

Table 8: Open Door Policy

An open-door policy means, literally that every manger's door is open to every employee. The purpose of an opendoor policy is to encourage open communication, feedback and to enable employees feel free to talk with any manager at any time. As it can be seen in item 1, table 8, 12(16.90\%) respondents replied Yes, which mean the bank have open door policy, 56(78.87\%) respondents replied No, which mean the bank do not have open door policy, and 3(4.23\%) said do not know. This indicates that the majority of employees said that the organization does not follow open door policy. So, the organization need to improved or create communication and relationship between managers and employees. As it can be seen in item 2, table 8, the majority of employees 11(91.67\%) said that this policy increases the performance of the organization by reducing the gap of the relationship between managers and employees.

\section{Finding, Conclusion and Recommendation}

\subsection{Findings}

In the organization $63.38 \%$ of respondents are male and also the majority age numbers of employees are middle age or Adolescent. Among employees who working in the organization the majority or $57.74 \%$ are master's holders. In the organization there is job security because the total employees or $100 \%$ are permanent.

Employees within the organization have high level of work experience this indicate that less turn over or high capacity to retain its employees, so we can conclude that the employees are motivated since they are working for long period in the organization. In the organization there are Financial and non-Financial motivational techniques. $71.83 \%$ or more than half of employees are not satisfied by the organization motivational activities or techniques. From the total respondent the majority $72.55 \%$ of employees are less salary payment and the remaining are different factors. In General, $63.38 \%$ of employees are preferred financial motivational techniques.

From the total number of respondent half of the employees $45.07 \%$ are say the level of motivation given in the organization are low. These show that there is motivation in the organization but it is not effective. The majority of respondent $56.34 \%$ say that the relationship between motivation and the organization performances are average this indicates that motivation and performances have in different relationship on the organization. As seen as in the analysis $95.77 \%$ of the respondent believes motivation has impact on the organization performances. The majority of respondent $90.14 \%$ are believes that employees should participate in the decision-making process. But $8.45 \%$ of respondents said that they do not participate in decision making process. The majority of respondent $59.15 \%$ said that the organization properly recognizes their contribution to the organization. This is good for employees to increasing the sense of belongingness or ownership.

\subsection{Conclusion}

Based on the data presentation, analysis and interpretation, the following conclusions are forwarded.

Employees are not satisfied in motivational technique given in the organization. The major factors are financial and non-financially. Dissatisfaction of employees caused because of less financial reward, low salary payment and nonfinancially is lack of training and promotion. Salary and lack of bonus are the major factors that affect employee's motivation in state bank of India, especially administrative staffs. Both employees and managers are positive or have good attitude toward inspiration/motivation. The employees believe that motivation has high impact on the organization performances by increasing the efficiency, profitability and belongingness of the organization.

Since the bank's Incentive package is unattractive, level of inspiration/ motivation used in the organization could not achieve high quality and effective work. Since the bank is not involving employees in the decision-making process. This is also considered as a factor which hinders motivation. This study reveals low relationship between employee's satisfaction, motivation and organization performances. The organization does not follow open door policy because of not focus on the motivational activities. This might cause communication gap between employees and managers. 


\subsection{Recommendation}

The researcher would like to make the following recommendation in views of what has been conducted by the data collected and analyzed.

The organization might need enhancing salary increment policy through specified time horizon. The organization might need to reduces the communication gap between employees and manager and improve open door policy.The organization might need to allow employees to participate in decision making process.The organization might need to increase and give high level of motivation activities such as financial motivation in order to enhance the satisfaction of employees in work place. The organization might need to implement motivational techniques depending on the employee's interest and desire before implementation. There is high need of employee's performance assessment and motivations need to the individual job. The organization might need to develop short term, middle and long-term training to employees.

\section{References}

i. Brief, A. P., \& Roberson, L., 1989. Job attitude organization: an exploratory study. Journal of Applied Social Psychology, 19: 717-727.

ii. Business Week (Cover Story), 2003. Is Wal-Mart too powerful? Oct 6, 2003, NY: Business Week: 100.

iii. Bunch, Jane, 2010. Bateman Vs. ASDA Stores. 2 March 2010, People Management Magazine.

iv. Filorina C., 2000. Commencement address. Massachusetts Institute of Technology, Cambridge, MA, June 2nd 2000.

v. Gelade, A. Garry \& Ivery, Mark, 2003. The impact of human resource management and work climate on organizational performance. Personnel Psychology, 56: 383-404.

vi. Griffeth, R. W., Hom, P. W. \& Gaertner, S., 2000. A Meta-Analysis of Antecedents and Correlates of Employee Turnover: Update, Moderator Tests, and Research Implications for the Next Millennium. Journal of Management, 26: 463-488.

vii. Heskett, J.L., T. Jones, G.W. Loveman, W.E. Sasser and L.A. Schlesinger, 1994. Putting the service-profit chain to work. Harvard Business Review 72 (March/ April): 164-174.

viii. Angelo Kincki and Robert Kreitner (2006): Organizational Behavior, key concepts, Skill and best practices (second edition)

ix. Ivancivich, John M. and Michael T.Mattession (2005): Organization Behavior and Management (Seven edition)

x. Steven L. MCshane and Mary Ann Von Glinow (2005): Organization Behavior (third edition)

xi. Biyani's Think Tank, Concept based notes (2011): human resource planning (first edition)

xii. Banker, R.D., G. Potter and D. Srinivasan. 2000. An empirical investigation of an incentive plan that includes nonfinancial performance measures. The Accounting Review 75 (January): 65-92.

xiii. Briggs, A. \& Coleman, M., 2006. Research methods in educational Leadership and management. London: SAGE.

xiv. Biyani's Think Tank, Concept based notes (2011): performance management and retention strategy (first edition).

xv. Biyani's Think Tank, Concept based notes (2012): banking services operations (new edition) 